Sistem Informasi

\title{
Penerapan Data Mining Pengaturan Pola Tata Letak Barang Pada Berkah Swalayan Untuk Strategi Penjualan Menggunakan Algoritma Apriori
}

\section{Marsono \\ Dosen Sitem Informasi STMIK Triguna Dharma, Jl.AH Nasution no.73 Medan Johor, Medan, 20142, Indonesia}

\section{KEYWORDS}

Data Mining, Tata Letak Barang, Algoritma Apriori

\section{CORRESPONDENCE}

Phone: 085763514201

E-mail: marsonotgd@yahoo.com

\section{PENDAHULUAN}

\section{Latar Belakang}

Toko Berkah Swalayan adalah toko yang bergerak di bidang ritel atau eceran. Dalam meningkatkan strategi penjualan ada beberapa cara yang dapat dilakukan oleh Toko Berkah Swalayan salah satunya adalah dengan melakukan pola tata letak barang. Pengaturan tata letak barang dagangan di rak toko sangat mempengaruhi minat konsumen dalam berbelanja.Terbukti bahwa keputusan membeli barang diluar perencanaan diambil konsumen saat melihat barang yang disusun dengan baik didalam toko, sehingga dapat disimpulkan bahwa pengaturan tata letak barang sangat mempengaruhi volume penjualan.Akan tetapi dalam pengaturan tata letak barang pada Toko Berkah Swalayan masih mengalami kendala yaitu kurangnya pengetahuan pihak Toko Berkah Swalayan dalam pengaturan tata letak barang.

Oleh karena itu dibutuhkan suatu sistem yang dapat membantu Toko Berkah Swalayan dalam menentukan pengaturan tata letak barang agar dapat meningkatkan strategi penjualan.Dalam beberapa literatur ada teknik yang dapat digunakan untuk mengatasi masalah tersebut diantaranya adalah Data Mining.Ada beberapa algoritma yang dapat digunakan untuk membantu dalam penelitian ini salah satunya adalah algoritma apriori.

\section{Rumuan Masalah}

Berdasarkan masalah yang telah diuraikan pada latar belakang maka dapat dirumuskan permasalahan dalam penelitian ini adalah :

1. Bagaimana merancang sistem Data Mining yang dapat membantu dalam pengaturan pola tata letak barang pada Berkah Swalayan untuk strategi penjualan?

2. Bagaimana menerapkan algoritma apriori dalam pengaturan pola tata letak barang pada Berkah Swalayan untuk strategi penjualan?

3. Bagaimana mengimplementasikan sistem Data Mining dalam pengaturan pola tata letak barang pada Berkah Swalayan untuk strategi penjualan dengan menggunakan algoritma apriori ? 


\section{Batasan Masalah}

Agar penelitian ini sesuai dengan permasalahan yang dibahas maka penelitian memberikan batasan masalahnya yaitu sebagai berikut:

1. Data yang digunakan adalah data struk penjualan Berkah Swalayan periode bulan Mei 2018.

2. Bahasa pemrograman yang digunakan adalah berbasis Desktop Programming.

3. Hasil keluarannya adalah berupa hasil pengelompokan data barang yang telah ditentukan nilai minumum support dan nilai minimum confidence.

\section{Tujuan Penelitian}

Adapun yang menjadi tujuan yang akan dicapai dalam penelitian adalah :

1. Untuk merancang sistem Data Mining yang dapat membantu dalam pengaturan pola tata letak barang pada Berkah Swalayan untuk strategi penjualan.

2. Untuk menerapkan algoritma apriori dalam pengaturan pola tata letak barang pada Berkah Swalayan untuk strategi penjualan.

3. Untuk mengimplementasikan sistem Data Mining dalam pengaturan pola tata letak barang pada Berkah Swalayan untuk strategi penjualan dengan menggunakan algoritma apriori.

\section{Manfaat}

Adapun beberapa manfaat dalam penelitian ini adalah sebagai berikut :

1. Dapat membantu Berkah Swalayan dalam melakukan pengaturan tata letak barang guna untuk strategi penjualan dengan lebih cepat.

2. Dapat membantu Berkah Swalayan dalam meningkatkan target penjualan.

3. Dapat dijadikan sebagai bahan referensi bagi peneliti berikutnya khususnya mengenai pengaturan pola tata letak barang dengan algoritma apriori.

\section{LANDASAN TEORITIS}

Istilah Data Mining dan Knowledge Discovery In Database (KDD) sering kali digunakan secara bergantian untuk menjelaskan proses penggalian informasi tersembunyi dalam suatu basis data yang besar. Sebenarnya kedua istilah tersebut memiliki konsep yang berbeda, tetapi berkaaitan dengan satu sama lain. Dan salah satu tahapan dalam keseluruhan proses KDD adalah Data Mining.

Knowledge Discovery Database (KDD) biasa disebut Proses Data Miningdanterdapat beberapa proses seperti gambar 1 berikut ini [1]:

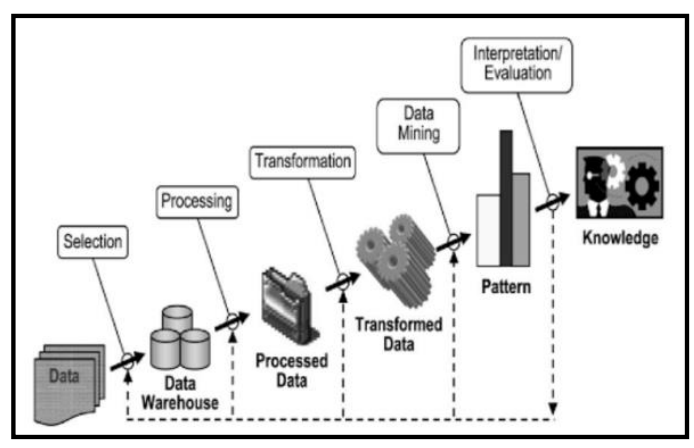

Gambar 1 Proses Knowledge Discovery In Database

\section{Data Mining}

Selain dari pengertian yang telah dijelaskan pada latar belakang, Data Mining disebut juga Knowledge Discovery in Database (KDD) didefenisikan sebagai ekstraksi informasi potensial, implisit dan tidak dikenal dari sekumpulan data. Proses Knowlegde Discovery in Database melibatkan hasil proses data mining (proses pengekstrak kecenderungan suatu pola data), kemudian mengubah hasilnya secara akurat menjadi informasi yang mudah dipahami.

Ada beberapa macam pendekatan yang berbeda yang diklasifikasikan sebagai teknik pencarian informasi/pengetahuan dalam KDD.Ada pendekatan kuantitatif, seperti pendekatan probabilistik seperti logika induktif, pencarian pola, dan analisis pohon keputusan. Pendekatan yang lain meliputi deviasi, analisis kecenderungan, jaringan saraf tiruan, dan pendekatan campuran.

Pada dasarnya ada enam elemen yang paling esensial dalam teknik pencarian informasi/pengetahuan dalam KDD yaitu:

1. Mengerjakan sejumlah besar data.

2. Diperlukan efesiensi berkaitan dengan volume data.

3. Mengutamakan ketetapan/keakuratan.

4. Membutuhkan pemakaian bahasa tingkat tinggi.

5. Menggunakan beberapa bentuk dari pembelajaran otomatis.

6. Menghasilkan hasil yang menarik.

\section{Fungsi Data Mining}

Menurut Sulistiyo [2] Data mining menganalisis data menggunakan tool untuk menemukan pola dan aturan dalam himpunan data. Perangkat lunak bertugas untuk menmukan pola dengan mengidentifikasi aturan dan fitur pada data. Tool data mining diharapkan mampu mengenal pola ini dalam data dengan input minimal dari user.

\section{Association Rule}

Association Rule adalah teknik data mining untuk menemukan aturan asosiasi antara kombinasi item. Contoh dari aturan asosiasi dari analisa pembelian di suatu pasar swalayan adalah dapat diketahui berapa besar kemungkinan seseorang membeli roti bersamaan dengan susu. Dengan pengetahuan tersebut pemilik pasar swalayan dapat mengatur penempatan barangnya atau merancang kampanye pemasaran dengan memakai kupon diskon untuk kombinasi barang tertentu Menurut Amirudin et al, 2007 [2] 
Aturan asosiasi akan menggunakan data latihan, sesuai dengan pengertian data mining, untuk menghasilkan pengetahuan. Pengetahuan untuk mengetahui item-item belanja yang sering dibeli secara bersamaan dalam suatu waktu. Aturan asosiasi yang berbentuk "if...then..." atau "jika...maka..." merupakan pengetahuan yang dihasilkan dari fungsi aturan asosiasi.

\section{Langkah-langkah Data Mining}

Menurut Feen dan Juan [3] ada empat tahap yang dilalui dalam Data Mining yaitu:

1. Tahap pertama: Precise statement of the problem (mendefinisikan permasalahan yang ingin diketahui). Misalnya ingin mengetahui apakah seorang customer berpotensi memiliki kredit macet, atau mengidentifikasi seorang customer apakah akan pindah ke kompetitor bisnis kita, dan lain sebagainya. Setelah menemukan pertanyaan bisnis yang perlu dijawab oleh data mining, selanjutnya tentukan tipe tugas untuk menjawab pertanyaan bisnis tersebut. Tugas dasar yang menjadi dasar algoritma data mining adalah klasifikasi, regresi, segmentasi, asosiasi dan sequence analisis.

2. Tahap kedua: Initial Exploration (Mempersiapkan data yang menjadi sumber untuk data mining termaksud data "cleaning" untuk mempelajari polanya). Setelah menemukan defenisi masalah, langkah berikutnya adalah mencari data yang mendukung defenisi masalah. Menentukan porsi data yang digunakan men-training data mining berdasarkan algoritma data mining yang telah dibuat. Setelah persiapan data selesai dilakukan, langkah berikutnya adalah memberikan sebagian dataa kedalam algoritma data mining.

3. Tahap ketiga: Model building and validation. Validasi apakah data mining memberikan prediksi yang akurat. Setelah training data selesai dilakukan, data mining tersebut perlu di-“uji" atau di-validasi keakuratannya terhadap data testing.

4. Tahap ke-empat: Deployment. Tahap ini memilih aplikasi yang tepat terhadap data mining untuk membuat prediksi.Proses deployment yang umum terdiri dari beberapa aktivitas yang saling berkaitan dengan perubahan yang mungkin diantara mereka. Aktifitas ini bisa terdapat pada sisi produsen atau sisi konsumen ataupun keduanya. Karena setiap sistem perangkat lunak itu unik, proses atau prosedur yang tepat antar setiap aktifitas sukar ditentukan.

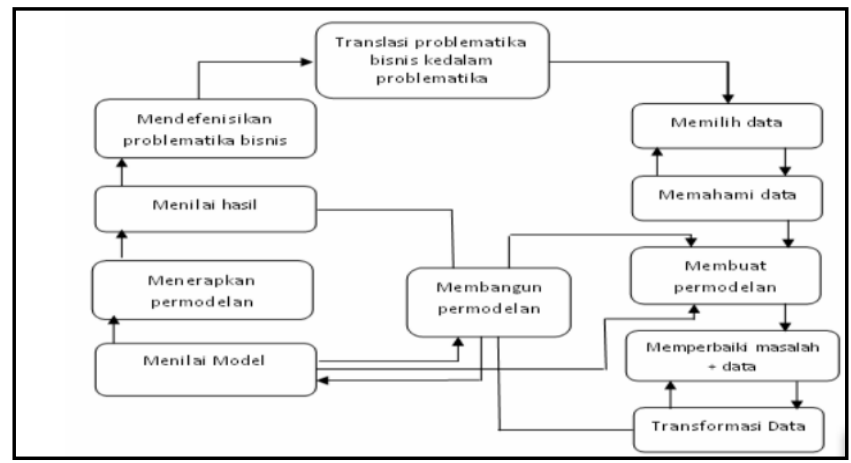

Gambar 2 Tahapan dalam Data Mining dan Membangun Model

Tahapan Association Rule

Analisis asosiasi dikenal juga sebagai salah satu teknik data mining yang menjadi dasar dari berbagai teknik data mining lainya. Khususnya salah satu tahap dari analisis asosiasi yang disebut analisis pola frekuensi tinggi (frequent pattern mining) menarik perhatian banyak peneliti untuk menghasilkan algoritma yang efesien Menurut Muhammad Ikhsan et al, 2007 [4].

Metodologi dasar analisis asosiasi terbagi menjadi dua tahap:

1. Analisa pola frekuensi tinggi, Tahap ini mencari kombinasi item yang memenuhi syarat minimum dari nilai support dalam database. Nilai support sebuah item diperoleh dengan memakai rumus berikut:

$$
\begin{aligned}
& \text { Support }(A)=\frac{\text { Jumlah Transaksi mengandung A }}{\text { Total Transaksi }} \times 100 \% \\
& \text { Sedangkan nilai dari support dua item diperoleh dari rumus berikut : } \\
& \text { Support(A,B) }=(A \cap B) \\
& \text { Support }(A \quad B)=\frac{\text { Jumlah Transaksi Mengandung A dan B }}{\text { Total Transaksi }} \times 100 \%
\end{aligned}
$$

2. Pembentukan Aturan Asosiasi Setelah semua pola frekuensi tinggi ditemukan, barulah dicari aturan assosiatif yang memenuhi syarat minimum untuk confidence dengan menghitung confidence aturan asosiasi “ jika A maka B “. Nilai confidence dari aturan " jika A maka B " diperoleh dari rumus berikut :

$$
\begin{aligned}
& \text { Confidence }=P(B A)= \\
& \frac{\text { Jumlah Transaksi Mengandung A dan B }}{\text { Jumlah Transaksi mengandung } A} \times 100 \%
\end{aligned}
$$

\section{Algoritma Apriori}

Algoritma apriori adalah suatu algoritma dasar yang diusulkan oleh Agrawal \& Srikant pada tahun 1994 untuk menentukan Frequent itemsets untuk aturan asosiasi Boolean. Algoritma Apriori termasuk jenis Aturan Asosiasi pada data mining.Aturan yang menyatakan asosiasi antara beberapa atribut sering disebut affinity analysis atau market basket analysis. Analisis asosiasi atau association rule mining adalah teknik data mining untuk menemukan aturan suatu kombinasi item. Salah satu tahap analisis asosiasi yang menarik perhatian banyak peneliti untuk menghasilkan algoritma yang efisien adalah analisis pola frequensi tinggi (frequent pattern mining). Penting tidaknya suatu asosiasi dapat diketahui dengan dua tolok ukur, yaitu :support dan confidence. Support (nilai penunjang) adalah persentase kombinasi item tersebut dalam database, sedangkan confidence (nilai kepastian) adalah kuatnya hubungan antaraitem dalam aturan asosiasi. Menurut Kusrini dan Emha Taufiq Luthfi [5].

\section{Tahap-tahap Algoritma Apriori}

Algoritma apriori dibagi menjadi beberapa tahap yang disebut narasi atau pass menurut Devi Dinda Setiawan [1].

1. Pembentukan kandidat itemset. Kandidat k-itemset dibentuk dari kombinasi (k-1)- itemset yang didapat dari iterasi sebelumnya. Satu cara dari algoritma apriori adalah pemangkasan kandidat $\mathrm{k}$-itemset yang subsetnya berisi k-1 item tidak termasuk dalam pola frekuensi tinggi dengan panjang k-1.

2. Penghitungan support dari tiap kandidat $\mathrm{k}$-itemset. Support dari tiap kandidat k-itemset didapat dengan menscan database untuk menghitung jumlah transaksi 
yang memuat semua item didalam kandidat k-itemset tersebut. Ini adalahjuga ciri dari algoritma apriori dimana diperlukan penghitungan dengan cara seluruh database sebanyak k-itemset terpanjang.

3. Tetapkan pola frekuensi tinggi. Pola frekuensi tinggi yang memuat $\mathrm{k}$ item atau kitemset ditetapkan dari kandidat k-itemset yang supportnya lebih besar dari minimum support.

4. Bila tidak didapat pola frekuensi tinggi baru maka seluruh proses dihentikan. Untuk lebih memahami proses algoritma Apriori maka berikut ini akan diberikan illustrasi penggunaan algoritma Apriori. Dengan menggunakan database pada gambar 3 dan mengasumsikan minimum support adalah 2 transaksi.

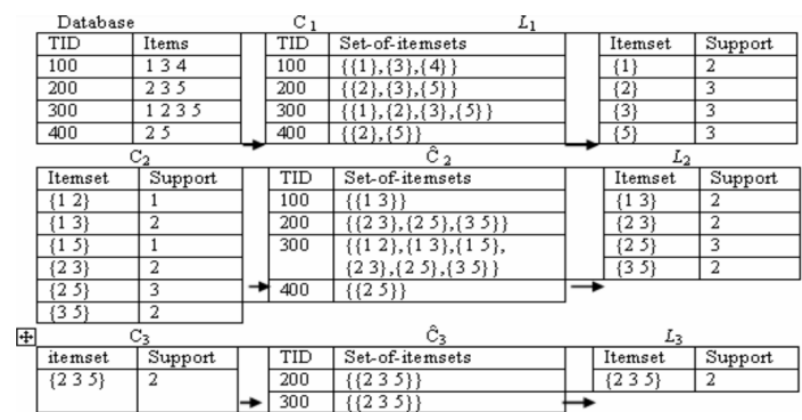

Gambar 3 Ilustrasi Algoritma Apriori

\section{ANALISA DAN PERANCANGAN}

\section{Analisis Permasalahan}

Toko Berkah Swalayan adalah toko yang bergerak dibidang ritel atau eceran. Dalam meningkatkan strategi penjualan ada beberapa cara yang dapat dilakukan oleh Toko Berkah Swalayan salah satunya adalah dengan melakukan pola tata letak barang. Pengaturan tata letak barang dagangan di rak toko sangat mempengaruhi minat konsumen dalam berbelanja.Terbukti bahwa keputusan membeli barang diluar perencanaan diambil konsumen saat melihat barang yang disusun dengan baik didalam toko, sehingga dapat disimpulkan bahwa pengaturan tata letak barang sangat mempengaruhi volume penjualan.Akan tetapi dalam pengaturan tata letak barang pada Toko Berkah Swalayan masih mengalami kendala yaitu kurangnya pengetahuan pihak Toko Berkah Swalayan dalam pengaturan tata letak barang.

Oleh karena itu dibutuhkan suatu sistem yang dapat membantu Toko Berkah Swalayan dalam menentukan pengaturan tata letak barang agar dapat meningkatkan strategi penjualan.Dalam beberapa literatur ada teknik yang dapat digunakan untuk mengatasi masalah tersebut diantaranya adalah Data Mining.

\section{Algoritma Sistem}

Algoritma sistem merupakan urutan langkah-langkah yang dilakukan dalam penyelesaian suatu masalah berdasarkan elemen-elemen yang saling integrasi dengan dituangkan kedalam bentuk kalimat untuk mencapai tujuan yang telah ditetapkan.Sehingga algoritma sistem yang jelas dan teratur sangat diperlukan dalam penyelesaian perancangan perangkat lunak.

\section{Identifikasi Data Transaksi}

2. Analisis Pencarian Pola Frekuensi Tinggi

3. Pembentukan Pola Kombinasi Dua Item Set

4. Pembentukan Aturan Asosiasi (Association Rule)

\section{Identifikasi Data Transaksi}

Identifikasi data dilakukan setelah data terkumpul dan sesuai dengan kebutuhan sistem ini.Data yang diambil merupakan data transaksi pembelian produk pada tanggal 11 februari 2018. Data tersebut adalah data sample dari data transaksi sebanyak 15 transaksi dan dapat dilihat pada table 1 . data transaksi.

Table 1 Data Transaksi

\begin{tabular}{|c|c|c|c|c|c|c|c|c|c|c|c|}
\hline No & Tgl & 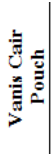 & 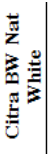 & 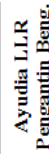 & 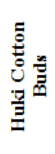 & 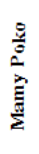 & 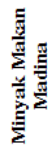 & 焉 & 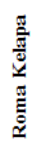 & 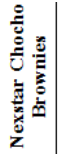 & 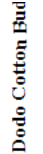 \\
\hline 1. & $11 / 02 / 2018$ & v & v & $\sqrt{ }$ & v & & v & & $\checkmark$ & & \\
\hline 2. & $11 / 02 / 2018$ & & v & v & & & $\checkmark$ & & v & & \\
\hline 3. & $11 / 02 / 2018$ & & & $\sqrt{ }$ & & & & 4 & & & \\
\hline 4. & $11 / 02 / 2018$ & 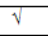 & $\checkmark$ & & & & $\checkmark$ & & & $\checkmark$ & \\
\hline 5. & $11 / 02 / 2018$ & & & & & v & & & & & $\sqrt{ }$ \\
\hline 6. & $11 / 02 / 2018$ & $\sqrt{ }$ & $\sqrt{ }$ & v & & & v & v & $\checkmark$ & & \\
\hline 7. & $11 / 02 / 2018$ & & $\checkmark$ & $\checkmark$ & & & & & $\checkmark$ & & \\
\hline 8. & $11 / 02 / 2018$ & v & & & & v & $\checkmark$ & & & & $\sqrt{ }$ \\
\hline 9. & $11 / 02 / 2018$ & & $\sqrt{ }$ & v & & & v & v & & & \\
\hline 10. & $11 / 02 / 2018$ & $\checkmark$ & & $\checkmark$ & v & & 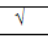 & & $\checkmark$ & & \\
\hline 11. & $11 / 02 / 2018$ & & $\sqrt{ }$ & & & & & V & & & \\
\hline 12. & $11 / 02 / 2018$ & V & & $\sqrt{ }$ & & & $\checkmark$ & & $\sqrt{ }$ & & \\
\hline 13. & $11 / 02 / 2018$ & & & & v & & 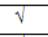 & 4 & & & \\
\hline 14. & $11 / 02 / 2018$ & V & $\sqrt{ }$ & v & & & $\checkmark$ & & $\sqrt{ }$ & & \\
\hline 15. & $11 / 02 / 2018$ & & & & $\checkmark$ & & $\checkmark$ & & & & \\
\hline
\end{tabular}

\subsubsection{Analisis Pencarian Pola Frekuensi Tinggi}

Dari table 1 Misalkan ada 15 transaksi dan kemudian dilakukan pencarian nilai Support Item dengan rumus: Mencari calon 1 Itemset dengan nilai Support sebagai berikut:

Tabel 2 intenset

\begin{tabular}{|c|l|c|c|}
\hline No $_{\mathbf{n}}$ & \multicolumn{1}{|c|}{ Produk } & Quantity & Support \\
\hline 1 & Vanis Cair Pouch & 7 & $46,67 \%$ \\
\hline 2 & Citra BW Nat White & 8 & $53,33 \%$ \\
\hline 3 & Ayudia LLR Pengantin & 9 & $60,00 \%$ \\
\hline 4 & Huki Cotton Buds & 4 & $26,67 \%$ \\
\hline 5 & Mamy Poko & 2 & $13,33 \%$ \\
\hline 6 & Minyak Makan Madina & 11 & $73,33 \%$ \\
\hline 7 & Minyak MakanTropical & 5 & $33,33 \%$ \\
\hline 8 & Roma Kelapa & 7 & $46,67 \%$ \\
\hline 9 & Nexstar Chocho Brownies & 1 & $6,67 \%$ \\
\hline 10 & Dodo Cotton Bud & 2 & $13,33 \%$ \\
\hline
\end{tabular}

Pembentukan Pola Kombinasi Dua Item Set

Pembentukan pola frekuensi 2-Itemset dibentuk dari Item-Item produk yang memenuhi Minimum Support yaitu dengan cara mengkombinasi semua Item kedalam pola kombinasi2-Itemset kemudian hitung nilai Support-nya dengan rumus :

$$
\text { Support }=\frac{\text { Jumlah Transaksi mengandung A dan B }}{\text { Total Transaksi }} \times 100 \%
$$

\section{Pembentukan Aturan Asosiasi (Association Rule)}

Untuk mencari aturan asosiasi terhadap langkah-langkah yang dilakukan sebelumnya, kemudian akan dihitung nilai Confidance dari setiap Item yang terdapat pada tabel berdasarkan rumus: 


\section{Confdance $=\frac{\text { Jumlah Transaksi mengandung A dan B }}{\text { Total Transaksi mengandung A }} \times 100 \%$}

Dari tahap-tahap yang telah dilakukan diatas, maka Item yang memenuhi Minimum Support $=40 \%$ dan Minimum Confidance $=70 \%$ maka dapat dilihat pada tabel 3 sebagai berikut:

Tabel 3 Aturan Asosiasi

\begin{tabular}{|c|c|c|c|}
\hline 10 & Pola 2 Itemset & Nilai Suppott & Nilai Confidance \\
\hline & Roma Kelapa,Winyak Makan Madina & $40.00 \%$ & $85.71 \%$ \\
\hline & Ayudia LLR Pengantin,Roma Kelapa & $46.67 \%$ & $77.78 \%$ \\
\hline & Ayudia LLR Pengantin,_inyak Makann Madina & $46.67 \%$ & $77.78 \%$ \\
\hline 4 & Citra BW Nat White, Minyak Makan Madina & $40.00 \%$ & $75.00 \%$ \\
\hline 5 & Citra BW Nat White,AyudiaLLR Pengantin & $40.00 \%$ & $75.00 \%$ \\
\hline 6 & Roma Kelapa,Ayudia LLR Pengantin & $46.67 \%$ & $100.00 \%$ \\
\hline 7 & 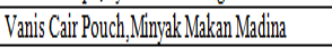 & $46.67 \%$ & $100.00 \%$ \\
\hline
\end{tabular}

\section{IMPLEMENTASI DAN PENGUJIAN}

Implementasi sistem merupakan tampilan interface program hasil perancangan, dengan implementasi sistem ini dapat mengetahui secara visual gambaran hasil dari sistem yang dirancang. Dengan implementasi sistem ini user akan dapat mengetahui bagaimana penggunaan program yang baik dan pengujian program apakan program benar-benar sudah sesuai dan benar-benar bisa digunakan tanpa ada error didalam program tersebut.

\section{Form Login}

Form ini merupakan tampilan form login untuk masuk kedalam form utama dengan cara mengisi nama user dan password.

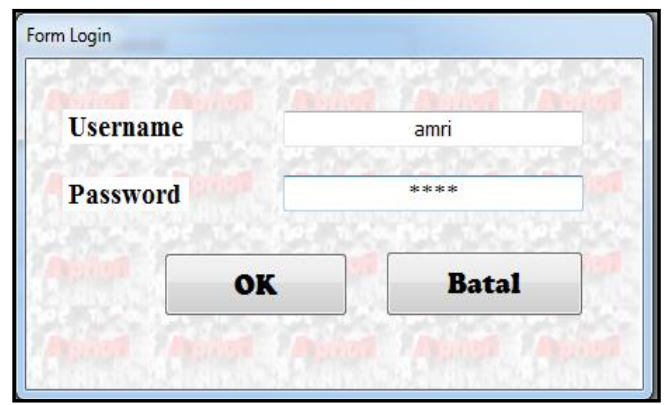

\section{Menu Utama}

Gambar 2 Form Login

Dengan menggunakan form dibuat menu utama program yang memiliki beberapa bagian menu program yaitu: file data, apriori proses dan exit dimana dalam masing-masing menu program terdapat beberapa sub menu pendukung lainnya yang berfungsi untuk menampilkan form-form yang dibutuhkan.

Didalam menu utama terdapat menu data yang memiliki dua (2) bagian sub menu program yaitu: file data dan apriori proses dimana dalam masing-masing sub menu program terdapat beberapa sub menu pendukung lainnya dengan tampilan masing-masing sub menu program dengan tampilan menu program dapat dilihat pada gamber 2 .

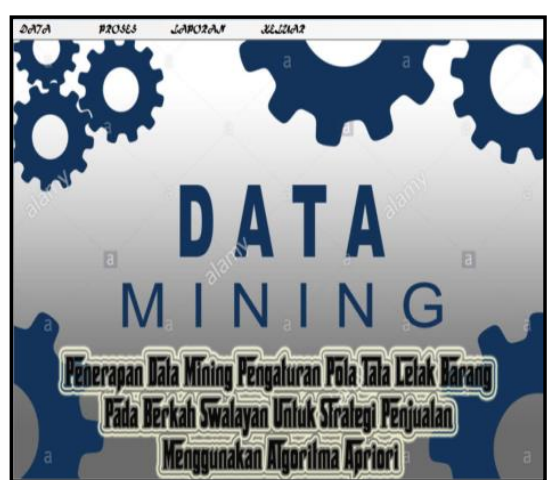

Gambar 3 Tampilan Form Menu Utama

\section{Form Data Barang}

Tampilan ini berisikan tentang data barang yang berfungsi sebagai media dalam memasukan data barang baru. Tampilan form dapat dilihat palda gambar 3 berikut ini.

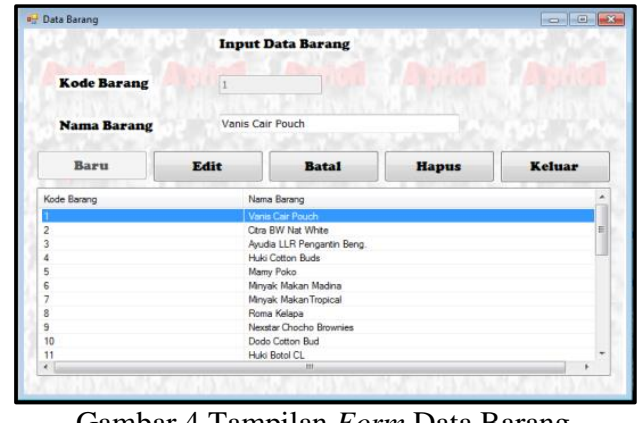

Gambar 4 Tampilan Form Data Barang

\section{Form Transaksi}

Form transaksi merupakan form yang berfungsi untuk mengelolah data transaksi yang digunakan untuk menginput data, mengedit data dan menghapus data. Tampilan form dapat dilihat pada gambar 4.4 berikut ini.

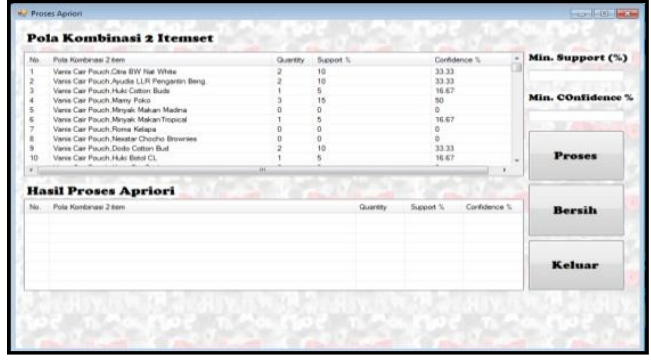

Gambar 5 Tampilan Form Transaksi

\section{Form Hasil Perhitungan}

Form hasil perhitungan merupakan form yang digunakan untuk menampilkan hasil perhitungan dari proses apriori. Tampilan form dapat dilihat pada gambar 6 berikut ini:

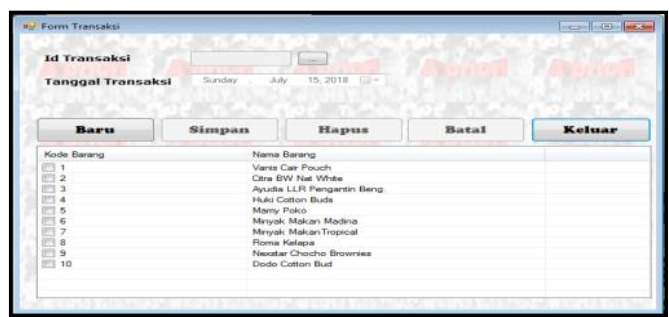

Gambar 6 Tampilan Form Hasil Perhitungan 


\section{Laporan}

Laporan merupakan tampilan yang menampilkan hasil laporan dalam menentukan tata letak barang pada Berkah Swalayan Menggunakan Algoritma Apriori. Tampilan form dapat dilihat pada gambar 7 berikut ini:

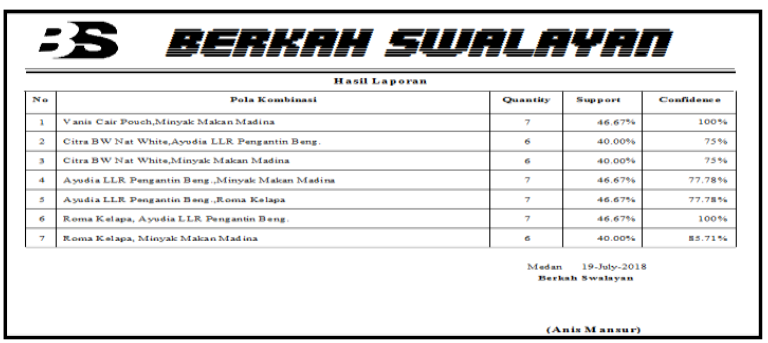

Gambar 7 Tampilan Form Laporan

\section{KESIMPULAN DAN SARAN}

\section{Kesimpulan}

Dari hasil perancangan aplikasi data mining dalam menentukan tata letak barang maka diperoleh suatu kesimpulan sebagai berikut:

1. Sistem ini dirancang agar dapat membantu dalam pengaturan pola tata letak barang pada Berkah Swalayan untuk strategi penjualan.

2. Sistem ini menerapkan algoritma apriori dalam pengaturan pola tata letak barang pada Berkah Swalayan untuk strategi penjualan.

3. Sistem ini di implementasikan untuk pengaturan pola tata letak barang pada Berkah Swalayan untuk strategi penjualan dengan menggunakan algoritma apriori apakah sudah sesuai dengan yang diharapkan.

\section{Saran}

Adapun saran-saran yang dapat disampaikan kepada pembaca dan kepada seluruh pihak yang berkaitan dengan perancangan sistem ini, yaitu:

1. Menambahkan menu laporan agar dapat melihat seluruh hasil penilaian.

2. Sistem dikembangkan lagi dengan di dukung dengan keamanan sistem dari serangan virus.

3. Interface aplikasi ini masih terlalu sederhana, disarankan dikembangkan menjadi sistem yang memiliki interface yang menarik dan mudah digunakan.

4. Disarankan aplikasi ini tidak hanya menggunakan Algoritma Apriori saja akan tetapi bisa dipadukan dengan metode-metode lainnya agar hasilnya lebih akurat.

5. Disarankan sistem ini dapat terhubung ke jaringan LAN dan internet.

\section{UCAPAN TERIMA KASIH}

Terima kasih kepada semua pihak yang mendukung penyelesaian artikel ini.

\section{REFERENSI}

[1] Jogiyanto. 2015. Analisis dan Desain. Yogyakarta: Andi

[2] Kusrini. 2015. Implementasi Data Mining Dengan Association Rule. Yogyakarta: Andi.

[3] Nofriansyah, D. 2014. Konsep Data Mining Vs Sistem pendukung Keputusan. Yogyakarta: Deepublish.
[4] Pramudiono. 2018. Apa itu Data Mining? Dalam http://datamining.japati.net/cgi-bin/indodm.cgi.Diakses tanggal 26 Februari 2018.

[5] Salahuddin dan Rossa. 2015. Rekayasa Perangkat Lunak Terstruktur dan Berorientasi Objek. Bandung: Informatika.

[6] Tampubolon.2013. Implementasi Data Mining Algoritma Apriori Pada Sistem Persediaan Alat-Alat Kesehatan. Medan: Informasi dan Teknologi Ilmiah (INTI).

[7] Turban, E., dkk. 2015. Decision Support Systems and Intelligent Systems. Yogyakarta: Andi Offset.

\section{NOMENCLATURE}

$\mathrm{J}_{\mathrm{c}} \quad$ meaning of $\mathrm{J}_{\mathrm{c}}$

\section{AUTHOR(S)BIOGRAPHY}

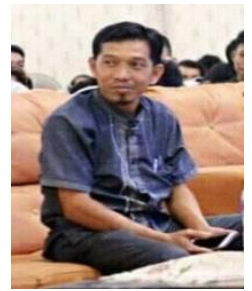

Author(s) Marsono, S.Kom, M.Kom

Nidn 0102057501

STMIK Triguna Dharma 